\title{
A biolistic process for in vitro gene transfer into chicken embryos
}

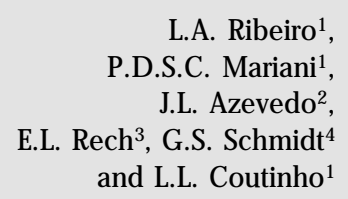

L.A. Ribeiro ${ }^{1}$,

P.D.S.C. Mariani,

J.L. Azevedo²,

E.L. Rech ${ }^{3}$, G.S. Schmidt 4 and L.L. Coutinho ${ }^{1}$

\author{
Departamentos de 1 Produção Animal, and \\ ${ }^{2}$ Genética, Escola Superior de Agricultura Luiz de Q ueiroz, \\ Universidade de São Paulo, Piracicaba, SP, Brasil \\ ${ }^{3}$ EM BRAPA/CENARGEN, SAIN Parque Rural, Brasília, DF, Brasil \\ ¿EM BRAPA Suínos e Aves, Concórdia, SC, Brasil
}

\section{Correspondence \\ L.L. Coutinho \\ Departamento de Produção Animal ESALQ, USP \\ Av. Pádua Dias, 11 \\ 13418-900 Piracicaba, SP \\ Brasil \\ E-mail: Ilcoutin@ carpa.ciagri.usp.br}

Research supported by FAPESP ( $\mathrm{No}$. 95/7457-6), EMBRAPA/CNPSA and CNPq. LLC, JLA, GSS and ELR are recipients of CNPq productivity scholarships and LAR is the recipient of a PhD scholarship from FAPESP.

Received February 23, 2001 Accepted June 20, 2001

\section{Abstract}

Chicken embryos kept in culture medium were bombarded using a high helium gas pressure biolistic device. To optimize the factors that affect transformation efficiency, the lac $Z$ gene under control of the human cytomegalovirus immediate early enhancer/promoter was used as a reporter gene. There was an inverse relationship between survival rate and transformation efficiency. The best conditions obtained for high embryo survival and high transformation efficiency were achieved with 800 psi helium gas pressure, $500 \mathrm{mmHg}$ vacuum, gold particles, an $8 \mathrm{~cm}$ DNA-coated microparticle flying distance to the embryo and embryo placement $0.5 \mathrm{~cm}$ from the center of the particle dispersion cone. Under these conditions, transformation efficiency was $100 \%$, survival rate $25 \%$ and the number of expression units in the embryo body cells ranged from 100 to 1,000. Expression of green fluorescent protein was also detected in embryos bombarded under optimal conditions. Based on the results obtained, the biolistic process can be considered an efficient method for the transformation of chicken embryos and therefore can be used as a model system to study transient gene expression and tissue-specific promoters.

\section{Introduction}

Various techniques have been developed and used to introduce exogenous genes into animal cells, aiming not only to study basic biological processes and gene regulation but also to produce transgenic animals. Methods using retrovirus infection and microinjection into the pronuclei of newly fertilized eggs are used when integration and stable gene expression are desired to produce transgenic animals (1). However, when transient gene expression is desired, other methods such as calcium phosphate coprecipitation, lipofection, electroporation and biolistic processes

\section{Key words}

- Biolistic process

- Chicken embryo

- Gene transfer

- ß-Galactosidase

- Green fluorescent protein

- GFP are used to transfer DNA in a variety of animal species (2-7).

In chickens, retrovirus infection has been successfully used to insert exogenous genes into the germline of young embryos $(8,9)$. Likewise, DNA transfer to blastoderm cells (10), primordial germ cells $(11,12)$ and somatic cells $(13,14)$ have been obtained. Direct microinjection of exogenous DNA into newly fertilized zygotes has also been developed; however, integration of this DNA into the germline is a rare event $(15,16)$. Other methods such as in ovo lipofection (4), electroporation $(5,6)$ and biolistic processes $(5,7,17)$ have been used in chicken embryos 
and adult chicken (18); however, only transient expression has been studied.

The biolistic process is a physical method used to introduce nucleic acids and other substances into cells or intact tissues through highly accelerated microparticles. This method, developed by Sanford and collaborators (19), has been widely applied and optimized in a variety of animal species (for reviews, see 20,21) due to its advantages, such as simultaneous bombardment of many cells, release of high doses of DNA, cotransformation with two or more plasmids, and independence concerning the use of genotypes, specific culture and tissue protocols $(3,22,23)$.

To assure the efficiency of DNA release within the cells and to reduce the harmful effects of this technique, optimization of physical and biological factors is necessary to obtain reproducible and consistent results $(3,24)$. The present report describes the development and optimization of an in vitro biolistic process of gene transfer to cultured live chicken embryos.

\section{Material and Methods}

\section{Chicken embryos}

Fertilized chicken eggs of the AgRoss lineage were incubated at $38^{\circ} \mathrm{C}$ for $42 \mathrm{~h}$. Embryos with 13 to 16 somites (developmental stage 11 or 12 , Ref. 25) were removed from the eggs, transferred to a Petri dish containing culture medium $(0.36 \% \mathrm{NaCl}$, $1 \%$ bacto-agar and $50 \%$ thin albumen), bombarded and incubated again at $38^{\circ} \mathrm{C}$.

\section{Expression vectors}

Two plasmids were used to evaluate transient expression of two exogenous genes, the lacZ gene from Escherichia coli ( $\mathrm{pCMVB)}$ and the green fluorescent protein (GFP) gene from Aequorea victoria (pEGFP-N1). Both genes were under control of the human cy- tomegalovirus (CMV) immediate early gene promoter/enhancer. The $\mathrm{pCMV} \beta$ plasmid was used for the experiments in order to optimize bombardment conditions. The protocol for plasmid precipitation onto gold or tungsten particles using $\mathrm{CaCl}_{2}$ and spermidine was described by Aragão et al. (26).

\section{Bombardment conditions}

A high-pressure helium gas apparatus based on the design described by Sanford et al. (27) was used to bombard the embryos. The distance from rupture and carrier membranes was $0.6 \mathrm{~cm}$. Carrier membrane flying distance to the stopping screen was $2.0 \mathrm{~cm}$, and distances from the carrier membrane to the embryo, corresponding to the DNAcoated microparticle flying distance to the embryo, were 8.0 and $11.0 \mathrm{~cm}$.

Two microparticle types were tested for plasmid precipitation: gold with diameters of 1.5 to $3.0 \mu \mathrm{m}$ and tungsten with a diameter of $1.2 \mu \mathrm{m}$ (M10, Sylvania Inc., New York, NY, USA).

\section{B-Galactosidase and GFP activities}

ß-Galactosidase (ß-gal) activity was detected by a histochemical assay. Embryos were fixed in a $4 \%$ paraformaldehyde solution for $5 \mathrm{~min}$ at $4^{\circ} \mathrm{C}$, followed by staining for $4 \mathrm{~h}$ at $37^{\circ} \mathrm{C}$ with a chromogenic substrate containing $100 \mathrm{mM}$ sodium phosphate, 1.3 $\mathrm{mM} \mathrm{MgCl}_{2}, 3 \mathrm{mM} \mathrm{K} \mathrm{K}_{4} \mathrm{Fe}(\mathrm{CN})_{6}, 3 \mathrm{mM}$ $\mathrm{K}_{3} \mathrm{Fe}(\mathrm{CN})_{6}$, and $1 \mathrm{mg} \mathrm{X}$-gal (5-bromo-4chloro-3-indolyl-ß-galactopyranoside)/ml. BGal expression was detected histochemically by the hydrolysis of X-gal to produce insoluble indigo. The resulting blue color indicated the location of B-gal activity in transformed cells. For light microscopic examination, embryos were embedded in LR white resin for transverse sectioning at $6 \mu \mathrm{m}$ thickness.

GFP activity was analyzed $24 \mathrm{~h}$ after bombardment, with no need for fixation or 
staining procedures. This protein was detected in live embryos with a fluorescent microscope. The synthesized fluorescent protein has a maximum excitation at $488 \mathrm{~nm}$ and maximum emission at $507 \mathrm{~nm}$.

Transformation was verified by the absence or presence of blue points (for B-gal) or green fluorescent points (for GFP), representing gene expression in a cell or group of cells (expression units). Embryos that showed reporter gene activity were classified into two categories: 1) expression in embryo body or extra-embryonic tissue or both (total expression), and 2) expression in embryo body.

Embryos that were completely degenerated at the time of fixation were discarded as it was not possible to determine if they expressed $\beta$-gal. These embryos were not considered in the calculation of survival rate or percentage of embryos expressing $\beta$-gal. Survival rate was verified by the presence of embryos with a heartbeat at the time of fixation. Non-bombarded embryos were used as negative control and did not show any staining or fluorescence.

\section{Statistical analysis}

Data concerning percentages of discarded embryos, survival rate and transformation efficiency were analyzed statistically by the chi-square test (28).

\section{Results and Discussion}

Different bombardment conditions were tested to maximize the number of transformed cells while maintaining tissue damage at an acceptable level. This testing is necessary because each species or cell type requires different conditions for DNA transfer $(23,24,29,30)$.

Parameters that affect transformation efficiency are velocity at which the microparticles reach the target, quantity of cells transformed and the effect of the shock wave on the targeted tissue. These parameters are controlled by a group of factors that interact amongst themselves, such as target positioning in relation to the center of the particle dispersion cone, microparticle size, DNAcoated microparticle flying distance to the target, helium gas pressure and vacuum inside the bombardment chamber (3).

\section{Embryo position relative to the center of the particle dispersion cone}

Experiments were initiated with gold microparticles, $8 \mathrm{~cm}$ DNA-coated microparticle flying distance to the embryo, three helium gas pressures (900, 1200 and 1500 psi), partial vacuum of $500 \mathrm{mmHg}$ and two embryo positions relative to the center of the particle dispersion cone ( 1 and $2 \mathrm{~cm}$ ). The center was not tested because according to Russell et al. (31) cells are seriously damaged in this area, becoming incapable of later division or growth.

Results in Table 1 show that all embryos placed at a distance of $1 \mathrm{~cm}$ presented B-gal activity. At this distance, 900 psi pressure produced the largest number of embryos expressing $\beta$-gal in the body cells $(88.9 \%)$. On the other hand, 1500 psi pressure produced the best results in embryos placed at 2 $\mathrm{cm}$ with $100 \%$ transformation efficiency compared to $62.5 \%$ for embryos under 1200 psi. Although embryos positioned at $1 \mathrm{~cm}$ showed better transformation efficiency and more transformed cells, tissue development was seriously hindered. In contrast, embryos placed at $2 \mathrm{~cm}$ from the center of the particle dispersion cone presented normal tissue development but few transformed cells. These results show an inverse relationship between number of transformed cells and damage to embryo development. In other words, the larger the number of transformed cells the greater the damage the embryos suffer. Russell et al. (31) and Gendreau et al. (32) observed the same phenomenon. Another important observation was the reduced num- 
ber of transformed cells in embryos placed at $2 \mathrm{~cm}$. This result could have been due to nonhomogenous microparticle dispersion since only a small number of particles reach the more distant embryos.

\section{Tungsten microparticles}

In an attempt to reduce damage to the embryo during bombardment, tungsten particles, which have a smaller diameter (1.2 $\mu \mathrm{m})$ than gold, were tested. $B-G a l$ expression was analyzed in 12 embryos bombarded with $900 \mathrm{psi}$ helium gas at $500 \mathrm{mmHg}$ and placed $1 \mathrm{~cm}$ from the center of the particle dispersion cone. Results showed that $75 \%$ of the bombarded embryos were transformed and all presented $\beta$-gal expression in the body cells. The number of expression units varied from 5 to 20 in the embryo body and from 20 to 50 in extra-embryonic tissue. Most embryos had a heartbeat $24 \mathrm{~h}$ after bombardment as well as a small delay in tissue development (data not shown).

\section{DNA-coated microparticle flying distance to the embryo}

In order to increase the number of expression units in the embryo body, the DNAcoated microparticle flying distance to the embryo was increased from 8 to $11 \mathrm{~cm}$ be- cause the greater the distance traveled by the microparticles the greater the particle dispersion area upon reaching the target (3).

Helium gas pressures of 900 and 1200 psi and a partial vacuum of $500 \mathrm{mmHg}$ were used to evaluate $\beta$-gal expression in embryos bombarded at 1 and $2 \mathrm{~cm}$ from the center of the particle dispersion cone (Table 2). B-Gal was expressed only in embryos bombarded at 1 and $2 \mathrm{~cm}$ from the center of the particle dispersion cone under 1200 psi. The 900 psi pressure proved to be very inefficient in transforming embryos placed at $2 \mathrm{~cm}$ because none of the embryos expressed B-gal activity. Most of the embryos, regardless of the conditions used, presented normal tissue development and a heartbeat at the time of fixation ( $24 \mathrm{~h}$ after bombardment). The number of expression units varied from 4 to 30 in the embryo body and from 10 to 40 in the extra-embryonic tissue.

Under these new conditions, embryo damage was minimized, but at the same time transformation efficiency and the number of transformed cells were reduced.

\section{Placement of embryos $0.5 \mathrm{~cm}$ from the center of the particle dispersion cone}

As the use of smaller tungsten particles and a longer flying distance $(11 \mathrm{~cm})$ reduced embryo damage, a new series of experiments

Table 1. Effect of helium pressure on ß-galactosidase (ß-gal) expression in embryos placed 1 and $2 \mathrm{~cm}$ from the center of the particle dispersion cone, using gold particles and $500 \mathrm{mmHg}$ vacuum.

\begin{tabular}{|c|c|c|c|c|c|c|c|c|}
\hline \multirow{2}{*}{$\begin{array}{l}\text { Helium } \\
\text { pressure } \\
\text { (psi) }\end{array}$} & \multicolumn{4}{|c|}{$1 \mathrm{~cm}$} & \multicolumn{4}{|c|}{$2 \mathrm{~cm}$} \\
\hline & $\mathrm{N}$ & $\begin{array}{c}\text { Embryos } \\
\text { with total } \\
\text { expression } \\
(\%)^{1}\end{array}$ & $\begin{array}{l}\text { Embryos } \\
\text { with } \\
\text { expression } \\
\text { in body } \\
\text { cells }(\%)\end{array}$ & $\begin{array}{l}\text { No. of e.u. } \\
\text { in embryo } \\
\text { body cells }\end{array}$ & $\mathrm{N}$ & $\begin{array}{c}\text { Embryos } \\
\text { with total } \\
\text { expression } \\
(\%)^{1}\end{array}$ & $\begin{array}{c}\text { Embryos } \\
\text { with } \\
\text { expression } \\
\text { in body } \\
\text { cells }(\%)\end{array}$ & $\begin{array}{l}\text { No. of e.u. } \\
\text { in embryo } \\
\text { body cells }\end{array}$ \\
\hline 900 & 9 & 100 & 88.9 & 44 & - & - & - & - \\
\hline 1200 & 9 & 100 & 66.7 & 45 & 8 & 62.5 & 12.5 & 3 \\
\hline 1500 & 9 & 100 & 77.8 & 59 & 6 & 100 & 50.0 & 9 \\
\hline
\end{tabular}

${ }^{1}$ Embryos with B-gal expression in body cells or extra-embryonic tissue or both. DNA-coated microparticle flying distance to the embryo was $8 \mathrm{~cm}$. e.u. = expression units. 
was conducted to evaluate transformation efficiency and survival rate of embryos placed $0.5 \mathrm{~cm}$ from the center of the particle dispersion cone. Bombardment conditions were 600 and 900 psi helium gas pressures and partial vacuum of $500 \mathrm{mmHg}$. Under these conditions, transformation efficiency was low for both pressures tested (37.5\% with 600 psi and $45.4 \%$ with 900 psi). The number of expression units was also very small for both embryo body and extra-embryonic tissue (less than 10 blue points). However, most embryos had normal tissue development and a heartbeat at the time of fixation $(24 \mathrm{~h}$ after bombardment).

The smaller number of expression units as well as the low transformation efficiency obtained in this experiment may have been due to particle deceleration resulting from the 11-cm distance traveled. Tests with increasing helium gas pressures were not conducted because higher pressures cause greater embryo damage $(3,31)$. Therefore, the DNAmicroparticle flying distance to the embryo was again reduced to $8 \mathrm{~cm}$. Another modification was the use of gold particles instead of tungsten. Particle material was changed because gold particles presented better results in previous experiments and have been more widely used in the literature for animal cells $(33,34)$.

Using gold particles, 11 embryos were bombarded with 900 psi helium gas pressure, $500 \mathrm{mmHg}$ vacuum and placement 0.5 $\mathrm{cm}$ from the center of the particle dispersion cone and $8 \mathrm{~cm}$ from the carrier membrane. All embryos bombarded presented enzymatic activity in both body cells and extra-embryonic tissue, representing a transformation efficiency of $100 \%$. The number of expression units varied from 20 to 200 in the embryo body and from 150 to 300 in the extraembryonic tissue, with a very homogeneous dispersion pattern. At the time of fixation (18 $\mathrm{h}$ after bombardment) no serious tissue damage was noted; however, embryos did not have a heartbeat and presented a slight delay in tissue development.

Based on these results, we can conclude that the conditions used in this experiment compared to those of previous tests achieved the best results regarding transformation efficiency, number of transformed cells and homogenous distribution of expression units throughout the embryos and extra-embryonic tissue. However, embryos still presented delayed tissue development and low survival rate.

\section{Helium gas pressure}

In order to reduce damage to the embryo, lower helium gas pressures were tested while maintaining the other variables unchanged.

\begin{tabular}{|c|c|c|c|c|c|c|c|c|}
\hline \multirow{2}{*}{$\begin{array}{l}\text { Helium } \\
\text { pressure } \\
\text { (psi) }\end{array}$} & \multicolumn{4}{|c|}{$1 \mathrm{~cm}$} & \multicolumn{4}{|c|}{$2 \mathrm{~cm}$} \\
\hline & $\mathrm{N}$ & $\begin{array}{c}\text { Embryos } \\
\text { with total } \\
\text { expression } \\
(\%)^{1}\end{array}$ & $\begin{array}{l}\text { Embryos } \\
\text { with } \\
\text { expression } \\
\text { in body } \\
\text { cells (\%) }\end{array}$ & $\begin{array}{l}\text { No. of e.u. } \\
\text { in embryo } \\
\text { body cells }\end{array}$ & $\mathrm{N}$ & $\begin{array}{c}\text { Embryos } \\
\text { with total } \\
\text { expression } \\
(\%)^{1}\end{array}$ & $\begin{array}{l}\text { Embryos } \\
\text { with } \\
\text { expression } \\
\text { in body } \\
\text { cells (\%) }\end{array}$ & $\begin{array}{l}\text { No. of e.u. } \\
\text { in embryo } \\
\text { body cells }\end{array}$ \\
\hline 900 & 6 & 50.0 & 0.0 & 0 & 4 & 0.0 & 0.0 & 0 \\
\hline 1200 & 22 & 72.7 & 27.3 & 17 & 20 & 35.0 & 30.0 & 9 \\
\hline
\end{tabular}

${ }^{1}$ Embryos with ß-gal expression in body cells or extra-embryonic tissue or both. DNA-coated microparticle flying distance to the embryo was $11 \mathrm{~cm}$. e.u. = expression units. 
Fifty-two embryos were bombarded with 600 , 700 and 800 psi helium pressures, vacuum of $500 \mathrm{mmHg}$, gold particles, placement of the embryos $0.5 \mathrm{~cm}$ from the center of the particle dispersion cone and $8 \mathrm{~cm}$ DNAcoated microparticle flying distance to the embryo. At the time of fixation (12 h after bombardment), the quantity of discarded embryos varied from 18.7 to $44.4 \%$ and the survival rate from 33.3 to $60.0 \%$ (Table 3 ). However, these differences were not statistically significant among the three pressures tested for either the quantity of embryos discarded or the survival rate $\left(\chi^{2}=2.545\right.$ and 1.783 , respectively, d.f. $=2$ ).

Concerning B-gal expression, all pressures presented $100 \%$ transformation, but only the 600 psi pressure had $100 \%$ B-gal expression in the embryo body cells. However, statistically there were no differences among the three pressures tested $\left(\chi^{2}=1.282\right.$, d.f. = 2). Nevertheless, as can be seen in Figure 1, when the number of expression units in the body cells is observed, only 800 psi pressure presented embryos with more than 1,000 blue points (Table 4).

Based on these results, optimal pressure was 800 psi. However, at the time of fixation, it was observed that most embryos bom- barded under this pressure, despite not having suffered any serious tissue damage, showed developmental delay.

\section{Vacuum level}

In order to reduce developmental delay in the embryos, three different vacuum levels were tested with 800 psi pressure: 400 , 500 and $600 \mathrm{mmHg}$.

The least amount of discarded embryos as well as a higher survival rate was obtained with $400 \mathrm{mmHg}$ vacuum. These results were expected because the lower the vacuum level the greater the air resistance and thus the slower the velocity at which the particles reach the embryo. Consequently, effects of the shock wave caused by the helium pressure are minimized, causing less embryo damage. Statistically, however, there were no differences among the different vacuum levels tested for the number of discarded embryos $\left(\right.$ mean $=25.9 \% ; \chi^{2}=3.181$, d.f. $=$ 2 ), survival rate (mean $=42.4 \% ; \chi^{2}=4.031$, d.f. $=2)$ and $B$-gal expression in the embryo body cells $\left(\right.$ mean $=97.2 \% ; \chi^{2}=2.726$, d.f. $=$ 2 ). The effect of vacuum on $\beta$-gal expression can only be noted by the number of expression units in the body cells. The only treat-

Table 3. Effect of helium pressure on percentage of discarded embryos, survival rate and ß-galactosidase (ßgal) expression in embryos placed $0.5 \mathrm{~cm}$ from the center of the particle dispersion cone, using gold particles and $500 \mathrm{mmHg}$ vacuum.

\begin{tabular}{|c|c|c|c|c|c|}
\hline \multirow{2}{*}{$\begin{array}{l}\text { Helium } \\
\text { pressure (psi) }\end{array}$} & \multirow[t]{2}{*}{$\mathrm{N}$} & \multirow{2}{*}{$\begin{array}{c}\text { Discarded } \\
\text { embryos (\%) }\end{array}$} & \multirow{2}{*}{$\begin{array}{l}\text { Sunvival } \\
\text { rate (\%) }\end{array}$} & \multicolumn{2}{|c|}{ Transformation efficiency } \\
\hline & & & & $\begin{array}{c}\text { Embryos with } \\
\text { total expression } \\
(\%)\end{array}$ & $\begin{array}{l}\text { Embryos with } \\
\text { expression in } \\
\text { body cells }(\%)\end{array}$ \\
\hline 600 & 16 & $18.7(3 / 16)^{1}$ & $53.8(7 / 13)^{2}$ & $100(13 / 13)^{3}$ & $100.0(13 / 13)^{4}$ \\
\hline 700 & 18 & $44.4(8 / 18)$ & $60.0(6 / 10)$ & $100(10 / 10)$ & $90.0(9 / 10)$ \\
\hline 800 & 18 & $33.3(6 / 18)$ & $33.3(4 / 12)$ & $100(12 / 12)$ & $91.7(11 / 12)$ \\
\hline
\end{tabular}

${ }^{1}$ Number of degenerated embryos $12 \mathrm{~h}$ after bombardment/total number of bombarded embryos ${ }^{2}$ Number of embryos with a heartbeat $12 \mathrm{~h}$ after bombardment/number of bombarded embryos - excluding the discarded ones.

${ }^{3}$ Number of embryos expressing ß-gal/number of bombarded embryos - excluding the discarded ones. ${ }^{4}$ Number of embryos expressing ß-gal in body cells/number of bombarded embryos - excluding the discarded ones.

DNA-coated microparticle flying distance to the embryo was $8 \mathrm{~cm}$. 
ment in which no embryo reached 1,000 expression units in the body cells was 400 $\mathrm{mmHg}$ vacuum. Differences between 500 and $600 \mathrm{mmHg}$ vacuums were verified as a function of the damage caused to the embryo tissue. Embryos bombarded with $600 \mathrm{mmHg}$ presented greater tissue damage at the time of fixation ( $24 \mathrm{~h}$ after bombardment). On the other hand, embryos bombarded with 500 $\mathrm{mmHg}$ presented a slight delay in development but no serious tissue damage (data not shown).

\section{Optimal conditions}

To determine the reproducibility of data generated under the optimized bombardment conditions, 70 embryos, placed $0.5 \mathrm{~cm}$ from the center of the particle dispersion cone and $8 \mathrm{~cm}$ from the carrier membrane, were bombarded with 800 psi helium pressure and 500 $\mathrm{mmHg}$ vacuum and then incubated for $24 \mathrm{~h}$ in culture medium before detection of $\beta$-gal activity.

The results showed a decrease in survival rate compared with Table 3 (from 40.0 to $25.4 \%)$. However, this difference was not statistically significant $\left(\chi^{2}=1.880\right.$, d.f. $\left.=1\right)$. The same results were obtained for total expression and expression in body cells. In spite of a decrease in the values obtained from 100 to $98.5 \%$ for total expression and $94 \%$ for expression in body cells, the $\chi^{2}$ values were not significant $\left(\chi^{2}=1.003\right.$ and 1.560 , respectively, d.f. $=1)$. A representative embryo bombarded under optimal conditions is shown in Figure 1C.

The following conditions were shown to be the best regarding transformation rate, number of transformed cells and damage to bombarded tissue: 800 psi helium gas pressure, $500 \mathrm{mmHg}$ vacuum, and embryo placement $8 \mathrm{~cm}$ from the carrier membrane and $0.5 \mathrm{~cm}$ from the center of the particle dispersion cone. These were considered to be the optimal conditions for in vitro gene transfer in chicken embryos.

\section{Histological sections}

Histological sections were prepared to analyze the depth of $\beta$-gal expression in embryos bombarded under optimal conditions. Histological transverse sectioning of the middle region of the embryo body revealed that most cells expressing $\beta$-gal were limited to the first layers of the somites (Figure 2), which demonstrates that the depth of B-gal expression was superficial because the embryos were placed dorsally at the time of bombardment. These results were also

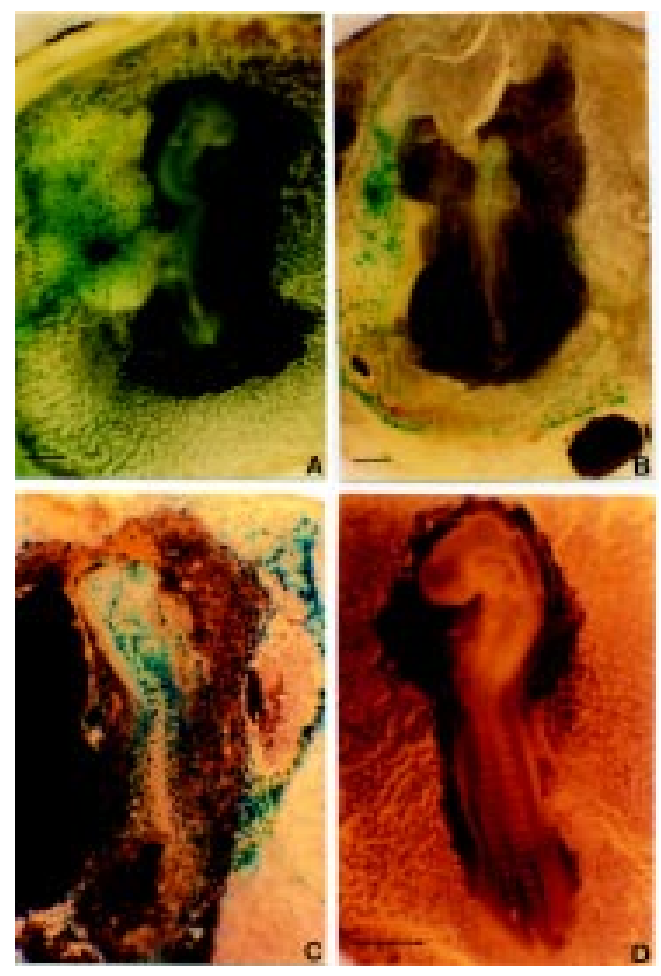

Figure 1. Embryos placed 0.5 $\mathrm{cm}$ from the center of the particle dispersion cone and bombarded with gold particles, 500 $\mathrm{mmHg}$ vacuum and $600 \mathrm{psi}(\mathrm{A})$, 700 psi (B) or 800 psi (C) helium pressure. D, Non-bombarded embryo (negative control). Blue points indicate ß-galactosidase expression. The DNA-coated microparticle flying distance to the embryo was $8 \mathrm{~cm}$. Scale bars $=1 \mathrm{~mm}$.
Table 4. Effect of helium pressure on number of expression units in body cells of embryos placed $0.5 \mathrm{~cm}$ from the center of the particle dispersion cone, using gold particles and $500 \mathrm{mmHg}$ vacuum.

\begin{tabular}{lcccc}
\hline Helium pressure (psi) & N1 & \multicolumn{3}{c}{ Embryos with expression in body cells (\%) } \\
\cline { 3 - 5 } & & 10 to 100 e.u. & 100 to 1,000 e.u. & over 1,000 e.u. \\
\hline 600 & 13 & $53.8(7 / 13)$ & $46.2(6 / 13)$ & - \\
700 & 10 & $70.0(7 / 10)$ & $20.0(2 / 10)$ & - \\
800 & 12 & $16.7(2 / 12)$ & $41.7(5 / 12)$ & $33.3(4 / 12)$
\end{tabular}

${ }^{1}$ Number of bombarded embryos, excluding the discarded ones. DNA-coated microparticle flying distance to the embryo was $8 \mathrm{~cm}$. e.u. $=$ expression units. 
Figure 2. Transverse section of the medial embryo region. Embryo bombarded under optimal conditions, displaying ß-galactosidase expression in the first layers of the somite (A). B, Nonbombarded embryo. NT, neural tube; N, notochord; S, somite. Scale bars $=100 \mu \mathrm{m}$. observed in skin, ear and liver tissues of bombarded mice (30) and mouse skeletal muscle fibers (35), where the introduced genes were found at a depth between 0.2 and $0.5 \mathrm{~mm}$ from the surface of the tissue.

\section{GFP expression}

The technique optimized using the lac $Z$ gene was then applied in new bombardments with the GFP gene. Results were very similar to those obtained with $B$-gal. The synthesized protein was detected in the embryo body cells as well as in the extra-embryonic tissue. The quantity of cells expressing the protein varied from 10 to 100 expression units (green points) in the embryo body cells and extra-embryonic tissue. Figure 3 illustrates the dorsal middle region of an embryo, depicting GFP expression in the neural tube,

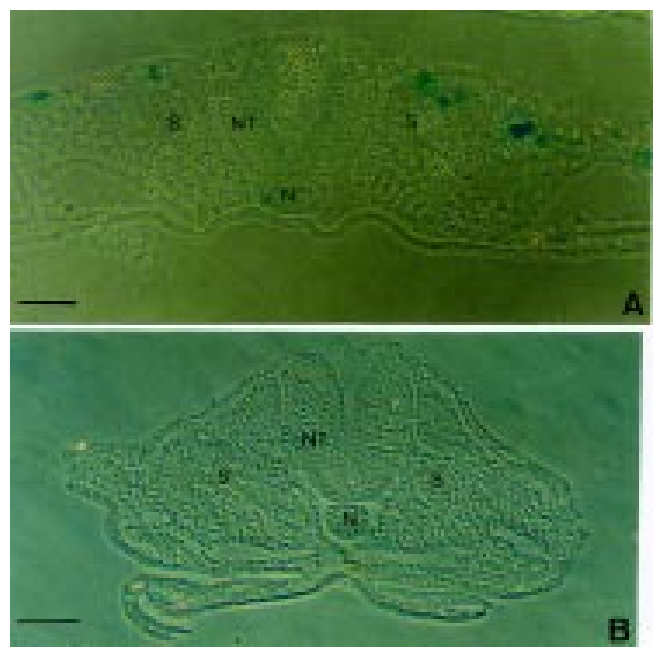

Figure 3. Embryo bombarded with 800 psi helium pressure and $500 \mathrm{mmHg}$ vacuum. Medial embryo region, showing neural tube, somites and extra-embryonic tissue. UV light (A) and overprint of UV and visible light images (B). Green points indicate cells expressing green fluorescent protein. Scale bar $=100 \mu \mathrm{m}$.
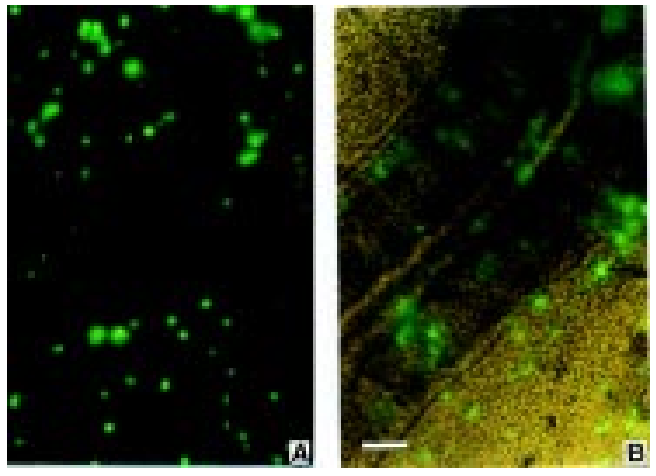

somites and extra-embryonic tissue. These results were expected as both genes were under the transcriptional control of the same promoter and under the same bombardment conditions.

DNA transfer to chicken embryos cultivated in culture medium was successful. The CMV promoter used caused strong expression in all embryo and extra-embryonic tissues, and the lac $Z$ and GFP reporter genes were easily detected. An efficiency of transformation of $100 \%$ and a survival rate of approximately $25 \%$ were obtained with gold particles, $500 \mathrm{mmHg}$ vacuum, $800 \mathrm{psi}$ helium pressure, and embryo placement $8 \mathrm{~cm}$ from the carrier membrane and $0.5 \mathrm{~cm}$ from the center of the particle dispersion cone. All efforts to improve the level of transformation using higher helium pressure or vacuum resulted in more expression but lower survival rates. Use of smaller particles to reduce embryo damage was unsuccessful because it resulted in lower transformation efficiency. Embryo position relative to the center of the particle dispersion cone was an important parameter for optimization since embryos placed $2 \mathrm{~cm}$ from the center presented lower transformation efficiency. Efforts to improve particle dispersion by increasing the distance of DNA-coated microparticles from the embryo resulted in fewer transformed cells. Previous reports have shown that the biolistic process can be used to transfer genes to chickens in ovo $(5,7,17)$. Li et al. (17) transformed primordial chicken embryo cells using an adapted surgical syringe and were able to detect the transgene in $7.5 \%$ of the bombarded embryos. Muramatsu et al. (5) used tungsten particles and 285 psi nitrogen to obtain $45.8 \%$ transformation efficiency and $42.9 \%$ survival rate. However, these values as well as the number and intensity of expression units were lower than those reported by Ribeiro et al. (7). These investigators obtained $68 \%$ transformation efficiency, $31.2 \%$ survival rate and an average of 100 expression units in the embryo body using 
gold particles, $600 \mathrm{mmHg}$ vacuum and 600 psi helium pressure. Under our conditions, a greater number and intensity of expression units were obtained. The fact that in our study the embryos had been removed from the eggs and bombarded in culture without the overlying layer of albumen could account for the difference between our results and those of other studies.

This report demonstrates the possibility of introduction and transient expression of a foreign gene in chicken embryos in culture medium using the biolistic process. Optimal bombardment conditions were obtained in order to establish a transformation system in chickens as a model for basic avian research, using a noninfectious, nonreplicative vector. In vitro transient gene expression introduced into cultured embryos may be adequate or desirable for many potential applications such as preliminary experimental studies of transgene expression, analyses of transcriptional control elements, expression of a circulating factor for a limited period and characterization of the in vitro expression of a specific promoter in various somatic tissues of avian embryos.

\section{Acknowledgments}

We thank Vera Maria Quecini for help with the biolistic experiments.

\section{References}

1. Gordon JW (1989). Transgenic animals. International Review of Cytology, 115: 171-229.

2. Keown WA, Campbell CR \& Kucherlapati RS (1990). Methods for introducing DNA into mammalian cells. Methods in Enzymology, 185: 527-537.

3. Sanford J C, Smith FD \& Russell J A (1993). Optimizing the biolistic process for different biological applications. Methods in Enzymology, 217: 483-509.

4. Demeneix BA, Abdel-Taweb $\mathrm{H}$, Benoist C, Seugnet I \& Behr J P (1994). Temporal and spatial expression of liposperminecompacted genes transferred into chicken embryo in vivo. Biotechniques, 16: 496501.

5. Muramatsu T, Mizutani $Y$, Ohmori $Y \&$ Okumura J (1997). Comparison of three nonviral transfection methods for foreign gene expression in early chicken embryos in ovo. Biochemical and Biophysical Research Communications, 230: 376-380.

6. Sugihara K, Park HM \& Muramatsu T (2000). In vivo gene electroporation confers strong transient expression of foreign genes in the chicken testis. Poultry Science, 79: 1116-1119.

7. Ribeiro LA, Azevedo J L, Aragão FJ L, Rech EL, Schmidt GS \& Coutinho LL (1999). In situ DNA transfer to chicken embryos by biolistics. Genetics and Molecular Biology, 22: 525-529.

8. Salter DW, Smith EJ, Hughes SH, Wright SE, Fadly AM, Witter RL \& Crittenden LB (1986). Gene insertion into chicken germ line by retroviruses. Poultry Science, 65 : 1445-1458.

9. Bosselman RA, Hsu RY, Boggs T, Hu S, Bruszewski J, Nicholson M, Schulz J A, Semon KM, Rushell $W$ \& Stewart RG (1989). Germ line transmission of exogenous genes in the chicken. Science, 243: 533-535.

10. Petitte J N, Clark ME, Liu G \& Gibbins AMV (1990). Production of somatic and germ line chimeras in the chicken by transfer of early blastodermal cells. Development, 108: 185-189.

11. Wentworth BC, Tsai H, Hallet J H, Gonzalez DS \& Rajcic-Spasojevic G (1989). Manipulation of avian primordial germ cells and gonadal differentiation. Poultry Science, 68: 999-1010.

12. Vick L, Li $Y \&$ Simkiss $K$ (1993). Transgenic birds from transformed primordial germ cells. Proceedings of the Royal Society of London, 251: 179-182.

13. Mima $\mathrm{T}$, Ueno $\mathrm{H}$, Fischman DA, Williams LT \& Mikawa T (1995). Fibroblast growth factor receptor is required for in vivo cardiac myocyte proliferation at early embryonic stages of heart development. Proceedings of the National Academy of Sciences, USA, 92: 467-471.

14. Itoh N, Mima T\& Mikawa T (1996). Loss of fibroblast growth factor receptors is necessary for terminal differentiation of embryonic limb muscle. Development, 122: 291-300.

15. Sang H \& Perry MM (1989). Episomal replication of cloned DNA injected into the fertilized ovum of the hen, Gallus domesticus. Molecular Reproduction and Development, 1: 98-106.

16. Love J, Gribbin C, Mather $\mathrm{C} \&$ Sang $\mathrm{H}$ (1994). Transgenic birds by DNA microinjection. Biotechnology, 12: 60-63.

17. Li Y, Behnam J \& Simkiss K (1995). Ballistic transfection of avian primordial germ cell in ovo. Transgenic Research, 4: 2629.

18. Kodihalli $S$, Haynes J R, Robinson $H L$ \& Webster RG (1997). Cross-protection among lethal H5N2 influenza viruses induced by DNA vaccine to the hemagglutinin. J oumal of Virology, 71: 3391-3396.

19. Klein TM, Wolf ED, Wu R \& Sanford JC (1987). High-velocity microprojectile for delivering nucleic acids into living cells. Nature, 327: 70-73.

20. Klein TM \& Fitzpatrick-McElligott S (1993). Particle bombardment: a universal approach for gene transfer to cells and tissues. Current Opinion in Biotechnology, 4: 583-590.

21. Furth PA (1997). Gene transfer by biolistic process. Molecular Biotechnology, 7: 139143.

22. Yang N-S, Burkholder J , Roberts B, Martinell B \& McCabe D (1990). In vivo and in vitro gene transfer to mammalian somatic cells by particle bombardment. Proceedings of the National Academy of Sciences, USA, 87: 9568-9572.

23. Klein TM, Arentzen R, Lewis PA \& Fitzpatrick-McElligott S (1992). Transformation of microbes, plants and animals 
by particle bombardment. Biotechnology, 10: 286-291.

24. Birch RG \& Franks T (1991). Development and optimization of microprojectile systems for plant genetic transformation. Australian J oumal of Plant Physiology, 18: 453-469.

25. Hamburger $\mathrm{V} \&$ Hamilton HL (1951). A series of nomal stages in the development of the chicken embryo. J ournal of Morphology, 88: 49-92.

26. Aragão FJ L, Barros LMG, Brasileiro ACM Ribeiro SG, Smith FD, Sanford J C, Faria J C \& Rech EL (1996). Inheritance of foreign genes in transgenic bean (Phaseolus vulgaris L.) co-transformed via particle bombardment. Theoretical and Applied Genetics, 93: 142-150.

27. Sanford J C, DeVit MJ , Russell J A, Smith FD, Harpending PR, Roy MK \& J ohnston SA (1991). An improved, helium-driven biolistic device. Technique, 1: 3-16.

28. Luginbuke RC \& Schlotzhauer SD (1987).
SAS/STAT ${ }^{\circledR}$ Guide for Personal Computers. 6th edn. SAS Institute Inc., Cary, NC, 555-573.

29. Zelenin AV, Alimov AA, Barmintzev VA, Beniumov AO, Zelenina IA, Krasnov AM $\&$ Kolesnikov VA (1991). The delivery of foreign genes into fertilized fish eggs using high-velocity microprojectiles. FEBS Letters, 287: 118-120.

30. Williams RS, J ohnston SA, Riedy M, DeVit MJ , McElligott SG \& Sanford J C (1991). Introduction of foreign genes into tissues of living mice by DNA-coated microprojectiles. Proceedings of the National Academy of Sciences, USA, 88: 2726-2730.

31. Russell J , Roy MK \& Sanford J C (1992). Physical trauma and tungsten toxicity reduce the efficiency of biolistic transformation. Plant Physiology, 98: 1050-1056.

32. Gendreau S, Lardans V, Cadoret J P \& Mialhe E (1995). Transient expression of a luciferase reporter gene after ballistic introduction into Artemia franciscana (Crus- tacea) embryos. Aquaculture, 133: 199 205.

33. J ohnston SA, Riedy M, DeVit MJ , Sanford J C, McElligott S \& Williams S (1991). Biolistic transformation of animal tissue. In Vitro Cellular and Developmental Biology, 27: 11-14.

34. Rech EL, De-Bem AR \& Aragão FJ L (1996). Biolistic-mediated gene expression in guinea pigs and cattle tissues in vivo. Brazilian J ournal of Medical and Biological Research, 29: 1265-1267.

35. Zelenin AV, Kolesnikov VA, Tarasenko OA, Shafei RA, Zelenina IA, Mikhailov W, Semenova ML, Kovalenko DV, Artemyeva OV, Ivaschenko TE, Evgrafov OV, Dickson G \& Baranovand VS (1997). Bacterial ß galactosidase and human dystrophin genes are expressed in mouse skeletal muscle fibers after ballistic transfection. FEBS Letters, 414: 319-322. 